\title{
Social Representations of the 'African Other' among participants of a Global Citizenship course in the Netherlands
}

\author{
Valerie de Koeijer, Eri Park, Marcin Sklad \\ Student of MA program, University of Oxford, Oxfordshire \\ v.dekoeijer@gmail.com \\ Assistant professor of psychology, University College Roosevelt, The Netherlands \\ e.park@ucr.nl \\ Associate professor of psychology, methods of social science and statistics, \\ University College Roosevelt, The Netherlands \\ m.sklad@ucr.nl
}

\begin{abstract}
This study aims to demonstrate processes by which Going Glocal, a Global Citizenship educational program based on Postcolonial Theory, can challenge social representation of the 'African Other' among participating students. Postcolonial Theory argues that the colonial history of countries directly affects the current state of previously colonized countries and contemporary relations between people from Europe and Africa. Critical Whiteness Theory is concerned with the privileged position of a 'white self', for whom these privileges usually do not become tangible. 15 university college students traveled to Namibia as part of 2012 Going Glocal project and semi-structured interviews were conducted with them directly after they came back, as well as focus groups at the very beginning and end of the program. Two students with opposite socio-economic and ethnical backgrounds were selected for this case study. Their responses were interpreted using Social Representations Theory as a theoretical framework, to reveal the divergent positioning the interviewees took, and were analyzed according to Postcolonial and Critical Whiteness Theory.
\end{abstract}

\section{Indexing terms/Keywords}

Global citizenship, Europe, Africa, Namibia.

\section{Academic Discipline And Sub-Disciplines}

Psychology; Cultural Studies.

\section{SUBJECT CLASSIFICATION}

Social Science

TYPE (METHOD/ APPROACH)

Case study

\section{Council for Innovative Research}

Peer Review Research Publishing System

Journal: Journal of Social Sciences Research

Vol .7, No.3

jssreditor.cir@gmail.com

www.jssronline.com 


\section{INTRODUCTION}

A person's perspective into the world is always bound to a certain identity and their position(ing) in the world (Park, 2011). Therefore, identity transformation processes have to get initiated to gain global outlook. In order to develop such outlook, not only socio-economic, historical and political knowledge has to be provided, but this has to take place in a setting which gives space to question and re-evaluate one's position in the world. This means that an individual brought up within a culturally monolithic environment, within a western society, has to learn to deconstruct and challenge Western notions about 'the rest of the world'. E.g. representations concerning Africa as a dark, homogenous block of violence, as Europe's fundamental 'other', which are ingrained in Western society (Dogra, 2012; Park, 2009, 2011a). Furthermore, thought processes need to get initiated to critically evaluate one's socio-economic privileges, how these are related to a European colonial history and how during colonial times the foundation was laid for the contemporary asymmetrical global institutional order.

University College Roosevelt (UCR), the International Honors College of Utrecht University, is a liberal arts and sciences college located in the Dutch province of Zeeland that has introduced Going Glocal. This is a global citizenship program, tailored around a need for citizens who 'think globally, act locally': citizens with a sense of agency, who hold the knowledge to contribute to social change and actively endorse their responsibilities; citizens who stand up for global justice (Pogge, 2002). The program utilizes a postcolonial approach to developmental education proposed by Latin American authors (Andreotti, 2006) and inspired by work of Spivak (2004) and Critical Global Citizenship theory (Andrzejewski \& Alessio, 1999). A certain part of the UCR student population has an ethnically homogenous background, namely Dutch. For many of these Dutch students college is the first prolonged exposure to a certain ethnical and cultural diversity.

Going Glocal is an ongoing project run with students in groups of fifteen, composed of three elements over the course of a year. Firstly, in a course of 60 teaching hours, students are taught about the (colonial) history of Namibia and contemporary youth culture through a post-colonial lens (Ferguson, 2006), including implications of deconstructed concepts of development, modernity and tradition. Based on this, the students develop their own teaching material to act as multipliers, and to teach pupils from local primary- and secondary schools (4 to 16 years) on a weekly basis over the course of a month what they have learnt about, e.g. Europe's and Africa's colonial history and the contemporary global trade system. Secondly, during the summer break students visit Namibia for three weeks. In the morning they teach in schools in a town called Opuwo or worked for various non-governmental organizations; in the afternoon, in collaboration with local teenagers, they renovate the pool of the local youth center, in order to interact with Namibian teenagers and to work on a common goal. Thirdly, in the fall semester, students follow a second college course and go back to the local schools to share their experiences in Namibia with the pupils.

In order for an individual to learn about and become willing to question their privileged position, they first have to become aware of their position in the world and their relation to 'the other', and they have to understand in which historical context this relation is embedded (Kilomba, 2010). Therefore the research question for our qualitative analysis reads as follows: What is the notion of the 'African other' concerning a) expectations of encountering 'the other' and b) 'self'-reflection processes of the Going Glocal participants' based on experiences in Namibia? What kind of reflection processes were initiated, and which social representations were challenged?

\section{Social Representations Theory}

For the analysis of our interview excerpts, Social Representations Theory (Moscovici, 1973/2000) will be used, as historical, cultural and macro-social conditions are deemed important for the interpretation of social-psychological phenomena and processes (Wagner et al., 1999). Social representations are defined as sets of values and beliefs shared within a certain group or community, influencing the behavior of the individuals within this group. They are used to relate to the outside world; to orientate oneself within this world and to enable communication between members of a group. They intervene in cognitive activity and have two roles. Firstly, they conventionalize objects, meaning that every object, person or event one encounters is placed in a certain category and is acted upon as such. Secondly, representations are prescriptive, thus are forced upon people (Moscovici, 2000). Social representations are highly influenced by the environment people live in as well as individual experiences. They evolve continuously along with the environment, and rely heavily on the dynamics of everyday life.

Social representations build and protect one's identity, which is both social and personal at the same time. Identities are constituted of being how one is identified by others, as well as how one identifies their self. The social representations of a specific group are closely interlinked with the identity of the individuals, and the individuals act upon the identity they create for themselves within the social representation of the group they belong to. Therefore, identity becomes a constraint as individuals seem to act within a created identity and the relation between the different identities of the social hierarchies within society. Identity thus places a constraint on what can be said and what can be heard (Gillespie \& Cornish, 2010). Identity and social representations theory are highly interlinked as they both serve for an individual to relate to the world around her or him. Through this understanding of identity, it can be explained why a person chooses certain social representations to reach specific ends and how individuals relate to the world around them. The perceived identity of a person with the social position one has in relation to others and how one sees oneself and others, influences the choices individuals make and which representations they draw on (Park, 2011).

The notion of social positioning is highly interlinked with both social representations and identity processes, since an individual's positioning of her- or himself is the expression of one's identity, thus influencing communication between 
individuals (Elejabarrieta, 1994). A social position is the position of an individual in society. "A position can be looked at as a loose set of rights and duties that limit the possibilities of action." (Harré \& Moghaddam, 2003, p. 5) Therefore the actions and behavior of an individual are implicitly limited by the position one is in and in order to maintain a certain position, one has to adhere to the rights and duties that are attached to it. One's position is to be seen in relation to other individuals or groups, thus the positioning of one person or group, often the dominant group, has an effect on relations between people (ibid.).

There are different genres of communication which correlate with these different representations of individuals, in which a division is made between in-groups and out-groups. The in-group is usually referred to as positive and intelligent, while the out-group is seen as different from the in-group, and is what the in-group is not (Marková, 2010). Besides protecting one's self and the in-group, the social representation of a certain group also determines and maintains the status that has been given to it. 'The other', who is part of an out-group, is identified as "those outside of, and implicitly subordinate to, the dominant group" (Joffé, 1999, p. 18). Representations of groups are not neutral; different groups may have different realities. These groups, however, may not have equal chances to express their reality; the dominant group has greater chances to do so. Therefore, social representations are always embedded in power relations which they help to perpetuate (Jovchelovitch, 1996).

\section{Post-colonial Theory}

Post-colonial theory (Said, 1978) provides an analytic framework which explores representations of power relations that have resulted from colonialism. In this context, Africa plays a special role as it represents Europe's fundamental 'other' and is constructed as a unity, ignoring the enormous variety between different countries. It is constructed as representing absence, darkness, poverty and failure (Ferguson, 2006), "as a homogenous block with violence, helplessness, human rights abuses and lack of democracy as its main characteristics" (Brookes, 1995, p. 465). In opposition to this, the West is constructed as 'light' and 'white'. Africa is constructed as the West's inferior other, according to which the 'black subject', or the 'African Other', is inferior to the 'white self'. The 'white subject' projects what they cannot find in themselves and disposes what they do not want to see in themselves onto the 'black other'. This distinction is not natural, but is part of the invention of a 'white self' (Kilomba, 2010). Critical Whiteness Theory uses 'white' as an analytic category to analyze how a white identity is constructed and to analyze this position in relation to 'others'. 'White Westerners' are not necessarily aware of the power relations at play in their usual environment, but nevertheless benefit from them (Frankenberg, 1993). The representations of people as 'white' and 'black' is significant to the construction of difference, hierarchy and power. Western individuals are constructed as agents and doers, while African individuals are represented as agents as well as victim. On the one hand, violence, repression and verbal wrangling are concepts used to refer to and describe African states, implicitly stating that African states benefit from Western aid and mediation (Brookes, 1995). On the other hand, "African civilians are predominantly constructed as affected participants, as beneficiaries of Western aid or victims of African repression, violence or natural disasters" (Brookes, 1995, p. 478). African citizens seem to become only victims of their own state. The role of the West is depicted as a positive agency, 'helping' Africans. Thus, "the West takes on the role of leadership based on the assumption of the moral high-ground which legitimizes and justifies its somewhat reluctant role of 'intervention' in Africa." (Brookes, 1995, p. 478) By doing this, the West is seen as a central and legitimate player in Africa. Furthermore, Africa is seen as having a lower level of progress than the West, as their political system is not as 'developed' as that of the West. Moreover, Western authorities and sources are seen as reliable and important, while its African counterpart is often discredited. This discourse on Africa fuels racist discourses in the West.

The idea that authority has instilled different, and sometimes competing and mutually excluding values in society that its citizens are not consciously aware of or adhere to is very present (Moscovici, 2011). Just as many discriminated groups, ethnic minorities are seen as a homogeneous group. This is visible in the case of Africa, an enormous continent seen as a unity, despite the great cultural diversity between the different cultures of the different countries (Ferguson, 2006). Racial distinctions between individuals within the group are not made explicit anymore and are thus taken for granted by individuals in society, turning the racial categories present in society today into common knowledge. Currently, groups of white Westerners usually construct themselves as not being personally involved in a racist discourse, which helps to perpetuate the discourse. According to Frankenberg (1993) the majority of the white Western group does not realize that in their 'natural', day to day environments, they are in a privileged position, not having to be worried about racist acts against them. The Going Glocal project has been explicitly created with the aim of giving students a place to become aware of this system, to become active citizens who are concerned about questions of global justice and know how to master the necessary skills to contribute to change. Going to Namibia and renovating a swimming pool there with visitors of a local youth center, was meant to give teenagers from Opuwo and the Dutch students the opportunity to interact with each other and to work on a common goal and making them aware of the systems in place.

\section{METHODS}

15 students participated in the Going Glocal program; eight of them were from the Netherlands, of which four had never visited a country outside of Europe. The remaining seven participants were white non-Dutch and people of color, from seven different countries of three continents. For the evaluation, focus group interviews were conducted at the very beginning of the program and the end and semi-structured individual interviews were conducted after students came back from Namibia. These interviews took roughly one hour. Based on the socio-demographic background, the participants were placed on a continuum concerning how strongly according to the theory they would construct the people in Namibia as 'the Other'. Two participants that could be placed on opposite ends of this continuum were selected for a comparative 
case study. The first interviewee (Marjolein ${ }^{1}$ ), has lived in the Netherlands her whole life and has never been to a country outside of Europe, the second interviewee (Angelina), is a half Dutch woman of color who was not born nor grew up in Europe, and moved to the Netherlands for her university education.

\section{ANALYSIS}

In this analysis the interplay between individual constructions of the world and their positioning of themselves will be investigated. Furthermore interviewees' positioning of themselves in relation to others, as well as the interviewees' awareness of their position will be discussed.

\section{Marjolein}

Before going to Namibia, Marjolein expressed her expectations and strong hopes on encounters with people in Africa on an 'equal' level.

I really, really hope that we overcome these boundaries. You know of, that is really something I hope to get out of it, and that is that I can actually talk with people like we are people here, accidentally in my class, so to say, that you can have a conversation. [...] I really hope that we can, that you can actually have a conversation with people with mutual respect and understanding. [...] If I can have that once, I am already really happy (Marjolein).

Marjolein defines the situation in the frame of in and out group, she focuses on the differences between her and the members of out-group: "Namibians". She envisions clear "boundaries" separating her from "them"; there is a division line she has to overcome before she can "actually have a conversation with people." The narrative is focused on I and us: "we are people here", which also suggests that she places the responsibility for overcoming the boundary of her in-group, possibly assigning herself and her group the active role which would conform with the social construction of White in Africa.

After Marjolein had visited Namibia, she also expressed several ideas concerning her position in relation to the people she met in Namibia, based on her experiences. She clearly expressed her role in Namibia in the following extract:

You're always trying to aim your conversation at development, because you're kind of as an anthropologist there (Marjolein).

The interviewee seems to hold a self-understanding which may be related to the discipline of the project. She is going to Namibia as a qualified professional, taking on a role in which the interviewee observes people in Namibia rather than interacts with them. By taking on this role, she also takes on a certain identity, which is interlinked with the social representations she holds of the people she met in Namibia. On the one hand Marjolein is trying to overcome boundaries between her and the people she meets, to improve her self-image, but on the other hand she holds a self-understanding to go to Namibia as "an anthropologists", a qualified professional, which sets up a boundary in itself and also places herself in the position of power in relation to the subjects of her inquiry. Furthermore, the relation between the actively 'researching' one and the one being 'researched' conforms to the stereotypical construction of Europeans as the ones who bring enlightenment to people in Africa who would be considered to be the 'wild objects' of anthropological studies (Ferguson, 2006).

Further on, Marjolein explains that she limited the use of her camera to avoid creating a distance:

I didn't really feel comfortable in the first place to take pictures there, because I didn't want to feel like a tourist. [...] It felt like the camera would create a distance between people living in Opuwo, living their daily lives, and me (Marjolein). On the one hand Marjolein tried to avoid any barriers and does not want to use a camera, but on the other hand she creates a distance by placing herself in a professional role. Both statements seem to create a barrier between the people she met in Opuwo and her. However, when by taking pictures she was aware of the barrier, which she did not want, she tried to eliminate it to make her feel more comfortable. On the one hand, Marjolein holds a social representation of herself as being concerned about global issues, thus not wanting to create an unnecessary barrier between her and the people she met. On the other hand, however, the social representation held by her in-group, of the power relations between her and the people she met in Namibia, is reflected in her behavior. Regarding these two extracts, a clash can be noted between these different representations.

In Marjolein's account, the 'African Other' does not occur; she does not make them part of her reflection, but merely focuses on her own role in Namibia. When Marjolein is asked how she was viewed by people in Namibia she answered:

I'm white so I'm smart. Teach us how to live the good life. Give us money. [That made me feel] horrible. [...] That people also look up to you. And l'm not someone to look up to (Marjolein).

When she was confronted with her white privileged position, she felt uncomfortable and tried to challenge this. Locals put her in a position not as an individual, but as a group member. The experiences of being reduced to a member of a group and being judged and treated accordingly, being prejudiced, is frustrating to her. Having started the Going Glocal project with the expectation of 'overcoming boundaries' and 'talking to people like we are people' did not turn out as expected. Her reaction to this was:

\footnotetext{
${ }^{1}$ For reasons of confidentiality, names have been changed
} 
So it was not my thing. So that was definitely a challenge, I mean, I've thought several times I'm just gonna stay in bed, I'm just not gonna go. Which I did twice (Marjolein).

Rather than interacting with people, Marjolein decided to stay in her room, isolated herself from the group and stated:

I didn't want to connect with people just because they were culturally interesting. [...] I didn't feel obliged to connect with them. Because I thought the only reason I would connect with you is because I have to because you're Opuwan and I'm Dutch [...] which maybe isolated myself a little (Marjolein).

Marjolein isolated herself not only from the locals, but also from her fellows. Her wish of respectfully interacting with people in Opuwo was not fulfilled. She reaffirms her division into in- and out-group, calling the out-group 'them' and literally objectifies 'them' as objects of the study. She feels as constantly being confronted with her privileged position so that after a while she chooses to isolate herself not only symbolically from the out-group but also physically.

Marjolein expressed emotions concerning her expectations and experiences in Namibia. Before going to Namibia, when being asked about who is in charge of tackling issues such as hunger and poverty, she answered:

I don't know, I got a little bit scared of the word, in charge. I don't know what that means, yeah, what that kind of means, because that suggests this form of relationship, so to say, where you have someone who is in charge... (Marjolein)

Further on, when being asked how exploitation issues could be tackled she freely admits that she has no concept:

Arrghh. Yeah, I wish, I wish I knew... (Marjolein)

Marjolein thus expresses frustration and fear concerning issues of responsibility and solving problems. After coming back and being confronted with such issues, she expressed feeling horrible and uncomfortable, as stated in quotes earlier.

In the following extract Marjolein describes encounters with different people she had met in Namibia. She had visited Windhoek, with 250.000 inhabitants the biggest and only city, and Opuwo, a small town with less than 8.000 inhabitants which is considered to be a place to go to if one wants to experience a 'traditional' life-style.

Windhoek: very active, very engaged. Very happy, very nice, very open for opportunities. Opuwo: kind of the opposite. I didn't really connect with the way how people work, but that's maybe also the case because I'm very much spoiled in the type of people that I'm surrounded with. I'm always surrounded with active and opportunistic [sic!] people (Marjolein).

Information provided by the semester long course before the trip about Namibia, its history and relations to Europe, did not seem to be helpful for Marjolein to overcome constructions of people in Africa as 'Europe's absolute other', and to connect to people, to interact with them. She rather seems to rank people she met in Opuwo as being 'lower' than people she is usually surrounded with. Marjolein's idea that she is 'very much spoiled', suggests that she believes people she is usually surrounded with, are on a 'higher' level than the people she was surrounded with in Opuwo, thus are better. By saying that she is usually surrounded with active people, Marjolein suggests that people in Opuwo were not.

On her last day of her voluntary work, teaching primary school students in a village called Opuwo, the principal of the school gave a speech which confronted Marjolein with the position of the people in Opuwo in relation to her and also put her as a European individual in a historical context. Earlier, Marjolein had uttered that she "really didn't like the principal".

l'll also never forget the speech of the principal in which he said that, [...] in 1602 the Dutch came to SouthAfrica and they have been developing our people ever since. You've been standing in their footsteps. And we thought like yeah, thank you for comparing us with murderers, colonizers, thank you. Which was really awkward (Marjolein).

In 1602 the Dutch East India Company (VOC) was founded, which is an organization that sent ships to East India via South Africa. This year, the Dutch travelled to East Asia, currently Indonesia, via South-Africa for the first time. The VOC established a refreshment station at the most southern point of Africa, currently Cape Town, and called it the Cape of Good Hope. Dutch people increasingly settled down at the Cape of Good Hope, and this was the start of the Dutch colonization of South-Africa (Gaastra, 2012). According to Post-Colonial Theory, the current view of people in Opuwo on people from Western Europe came into existence during these colonial times, when the colonized were forced to obey the colonizers. By suggesting that Marjolein was following in the footsteps of the colonizers, the principal directly confronted the interviewee with the power relation between the group of UCR students and the people from Opuwo. White people see themselves as individuals and think of other white people as individuals, whereas 'others' are perceived as groups. This does not happen consciously, but is one of the non-tangible privileges of the white position (Frankenberg, 1993).

What Marjolein experiences here is that she is reduced to a member of a group and is treated according to the properties to which this group is defined, which are outside of her power to define. Rather than being perceived as a member of a student group who has come to Africa to learn themselves and to be at a local school from which the local community would also benefit, she is put in a historical line with murderers. It is a very new experience for Marjolein to learn how she is perceived by 'the other', by people of color living in an African country. It is a painful experience for her being put in a tradition of violence and murder. What she faces is the gaze of 'the Other' onto her 'white self'. Marjolein is confronted here with an aspect of the 'white subject' that is painful and that she does not want to see, therefore, she projected this 
negativity onto the 'black other' (Kilomba, 2010). Thus, rather than acknowledging the colonial history of her country, Marjolein rejected this and disliked the principal of the school, among others for comparing her to the colonizers.

\section{Angelina}

Angelina is a woman of color who grew up outside of Europe, and moved to the Netherlands for her university education. Firstly, she reflects on her position and her background:

I do not start from a wealthy background. My parents are mostly from a poor background and then personally I do know what it is like to not have anything (Angelina).

Here, Angelina positions herself in relation to the other UCR students she was travelling to Namibia with. She re-interprets her self-understanding in relation to the other students in the group. She grew up in a poor family, thus she can relate well to people who do not have anything, as was the case for many people in Namibia. Before going to Namibia, talking about what to expect regarding her encounter with Namibians she expressed:

I just imagined them to be the same way as they would be in [country of birth]. Take life easy, it's all about your parents and your grandparents and hanging out with your friends and things like this. (Angelina)

Further on, Angelina told a story about when she started discussing menstruation in one of the classes with just girls. She said:

I felt like I fit in. I mean, we all had that, we're all women sort of and you know, there was not that age difference and you're this color, you're that color, nothing, we were just all women who went through this and think it was great to not focus on how we were different but actually on what we had in common (Angelina).

Herewith the interviewee focused on similarities rather than differences and compared the people she met in Namibia to herself. She empathized with them and took their perspective. Even though there were differences, the interviewee focused on the similarities, which gave both her and the children in the classroom a sense of belonging and put everyone on an equal level. Thus, the social representations Angelina holds about herself and her family and friends, are similar to the ones she holds about the people she met in Namibia.

Angelina expresses emotions she has concerning the topics that are discussed in the interview. For instance, when the interviewee is asked which emotions are elicited when talking about topics such as inequality and exploitation between people in different positions in the world, she answer with one word: anger. Moreover, the interviewee shows that the issues under discussion are a major part of her day-to-day life. When asked whether she talks about the topics under discussion, such as inequality, with her friends, she answers: definitely. Throughout the interviews, the emotions Angelina elicits concerning the issues that are discussed, show coherence in her account and perspective on the issues, suggesting she holds a clear set of thought through social representations. She goes further than just questioning issues on a small scale and finding short term solutions. When asked what her solution would be to problems of for instance inequality, her answer was no more money. Herewith she questions the entire system that the economy of the world has been based on; monetary exchange. The interviewee expresses anger towards the situation and questions the system the world is built around. Whereas others in the group might have been taught about the value of money and issues such as inequality, Angelina has experienced it in her own life.

Angelina commented on exactly the scene which Marjolein spoke about:

During the sessions it was very often that people [students] say certain things that I thought well, it's very wrong to say such things. One of the, most bold things for me was, one person in the group said, I don't see why I should interact with the youth just because they are culturally attractive. And I was thinking to myself well, that's just really wrong to say like that because it is actually a very polite way of saying I don't want to talk to people here because they are different, because they are black, because they are poor, they are not educated. [...] And in the beginning I thought maybe it is just me and I'm being prejudiced, but even when I went home and I told people $[\ldots]$ they were really like, shocked. (Angelina)

In this situation Angelina did not dare to trust her gut feeling, but when she came back home and shared her experiences with other people of color her feelings of shock were reaffirmed. Rather than relying on her own interpretation of the events, she distrusts her own gut feeling and initial interpretation. While the majority of the UCR students are in the white privileged position, Angelina is not and identifies with the people she met in Namibia, who are by some other students in the group seen as the 'African Other'.

All students in the group are part of a society where white people are in a privileged position but do not realize this, while Angelina, who is not the 'white subject', is not in this position. One of the privileges of being in this position is deciding who you want to talk to and who you do not want to talk to. Based on the criteria that the interviewees in the white privileged position have made themselves, such as being similar to them, they can choose whether or not to approach someone. Since Angelina is not in this position, she does not have this privilege and rather than talking only to people she perceives as similar, she interacts with the 'African other', and sees them as an 'equal' rather than an 'other'. In a society where the 'white subject' is always in the privileged position. Angelina first assumed that she was wrong or prejudiced, since she is not in this white privileged position herself, while the people she is countering are. However, when going back home and telling people, they were shocked as well, confirming Angelina's position. Here it becomes clear that the people with 
similar backgrounds as Angelina support her position, while the majority of the people she is surrounded with in Namibia and overall during her studies holds a different point of view.

\section{Marjolein and Angelina}

There is dramatic difference in how the two students perceived Namibians and reacted to the encounter with them. The white, Dutch student, encountered the 'African Other', she always perceived Namibians as out-group, while the student of color had little problem identifying with Namibians and rather saw them as equal. The two students thus constructed the Namibians on opposite ends of the continuum, ranging from 'The African Other' to people equal to oneself. Marjolein constructed her role in Namibia as an anthropologists, who only wants to connect to people who fit her criteria, thus are similar to her. Furthermore, Marjolein left the Netherlands with the hope and expectation to have conversations with people in Opuwo on an 'equal level', yet created boundaries for herself. Marjolein became painfully aware of her white privileged position, and is the 'white subject' as opposed to the 'African Other'. She felt addressed as a white European, put in a historical line with murderers, which is very different from her expectations and self-understanding. Even though Marjolein benefits from these historical events, she does not see the connection to her personally, as theorized in postcolonial theory (Ferguson, 2006). Angelina identifies and empathizes with the people she met in Namibia. She grew up in a non-Western country and therefore has experienced the situation that many of the people she met in Namibia are in herself. Rather than being the 'white subject', Angelina positions herself as the 'African Other' and identifies with this position. She thus identifies more with the people she met in Namibia, than with the people she is travelling to Namibia with. She focuses on similarities rather than differences between her and the people she met in Opuwo, and takes on the perspective of the people in Opuwo rather than having a Western perspective and imposing this onto others.

The research question was: What is the notion of the 'African other' concerning a) expectations of encountering 'the other' and b) 'self'-reflection processes of the Going Glocal participants' based on experiences in Namibia? What kind of reflection processes were initiated, and which social representations were challenged? It can be concluded that on the one hand, the issues that are the core of the Going Glocal project, are issues that are interwoven in Angelina's daily life. Angelina does not see the people she met in Namibia as 'the other', she sees herself as equal to the people she met. The social representations; the values and beliefs shared within a certain group or community (Moscovici, 2000), Angelina holds about herself, are similar to the ones she holds for the people she met in Namibia. For Marjolein, on the other hand, this was not the case. Marjolein did not realize she is in a white privileged position, and when she was confronted with it and made aware of it, the social representations she holds, her identity and position were challenged, and self-reflection processes regarding these topics were triggered. The behavior that might have been expected from her by for example Angelina, would not fit her identity. Therefore, in order to change her behavior to adjust to the situation, her set of social representations and therewith her identity and position should also change (Moscovici 2000), which made her uncomfortable. Rather than engaging in extensive self-reflection and changing her social representations, she dealt with this by isolating herself from the group and the people she met in Namibia. One's identity constrains what can be said and heard (Gillespie \& Cornish, 2010), and this can be seen in the behavior of Marjolein. Hearing about the colonial history of her country and speaking to the people she met in Namibia as equals did not fit the identity and social representations Marjolein holds, thus she avoided these instances. When studying development aid in a critical way for the first time at UCR and within Going Glocal, Marjolein was confronted with her positions in the system of inequality for the first time.

\section{FINAL THOUGHTS}

Global citizenship is not an inherent position that one is born with nor does this position necessarily remain identical throughout life. Global Citizenship skills depend both on one's upbringing and background, but can change significantly throughout an individual's life. Thus, one can be raised according to certain values and standards, however, throughout life these values can change and one can adapt different viewpoints. A global citizen has a global outlook on the world, thus does not only consider their direct environment, but also other countries and the effects actions of the country they live in have on countries other than their own. In order to obtain this position, individuals need to be informed not only about events that directly influence them, but also about world issues, such as colonialism. A sense of acknowledgement and justice is important for individuals to take the responsibility to change unequal power relations between different parts of the world. For example, people living in countries that were historically the colonizer do not feel responsible for the actions of their ancestors, since these events have taken place in the past; however, they still benefit from the outcomes today. Similarly, people living in colonized countries are still negatively affected by the actions of the colonizers and similar actions of high-income countries, their governments and the citizens who brought them into power and the corporate world today (Park, 2012).

For many students, the project can be seen as successfully providing a setting to sharpen their global citizenship competence. For some students it was a time of firsts: the first time outside of Europe; entering a world where the 'other' is in the majority; and the first time being confronted with not so to be proud of historical roots of one's own privileged position. These first experiences provided the setting for challenging and reaffirming constructions of 'the other' that 
students already held. Also, it provided a platform for questions about their identity and how they are positioned by others in a wider setting beyond the Netherlands.

\section{ACKNOWLEDGMENTS}

This research is supported by a grant from 'Subsidies for Citizenship and Development Cooperation' (SBOS), a program of the Dutch Ministry of Foreign Affairs. Special thanks to Dr. Rolando Vasquez, Prof. Barbara Oomen, Dr. John Friedman, Dr. Fatima Mueller-Friedman, Vicki Haverkate and Anneke Oss.

\section{REFERENCES}

[1] Andreotti (2006). The contributions of postcolonial theory to development education

[2] Andreotti, V (2006) 'Soft versus critical global citizenship education', Policy \& Practice. A Development Education Review, 3, 40-51.

[3] Andrzejewski, J., \& Alessio, J. (1999). Education for global citizenship and social responsibility (Progressive Perspectives: 1998-99 Monograph Series, 1[2]). http://www.uvm.edu/ dewey/monographs/mono.html (accessed February 15th, 2010).

[4] Benedict, R. (1959). Race and Politics. New York: Viking Press.

[5] Brookes, H. (1995). 'Suit, Tie and a Touch of Juju' - The Ideological Construction of Africa: A Critical Discourse Analysis of News on Africa in the British Press. Discourse \& Society, 6(4), 461-494.

[6] Dogra, N. (2012). Representation of Global Poverty - Aid, Development and International NGOs. London: I. B. Tauris.

[7] Elejabarrieta, F. (1994). Social Positioning: A Way to Link Social Identity and Social Representations. Social Science Information, 33, 241-253.

[8] Ferguson, J. (2006). Global Shadows. Africa in the neoliberal world order. Durham and London: Duke University Press.

[9] Frankenberg, R. (1993). White Women, Race Matters: The Social Construction of Whiteness. Minneapolis: University of Minnesota Press.

[10] Gaastra, F. S. (2012). Geschiedenis van de VOC. Zutphen: Walburg Pers

[11] Gillespie, A., \& Cornish, F. (2010). What can be said? Identity as a constraint on knowledge production. Papers on Social Representations, 19, 5.1-5.13.

[12] Harré, R., \& Maghaddam, F. (eds.). (2003). The Self and Others - Positioning Individuals and Groups in Personal, Political and Cultural Contexts. Westport, CT: Praeger.

[13] Joffé, H. (1999). Risk and the Other. Cambridge: Cambridge University Press.

[14] Jovchelovitch, S. (1996). In Defence of Representations. Journal for the Theory of Social Behavior, 26(2), 121-135.

[15] Kilomba, G. (2010). Plantation Memories. Münster: Unrast-Verlag.

[16] Marková, I. (2010). Gerard Duveen on the epistemology of social representations. Papers on Social Representations, 19, 4.1-4.9.

[17] Moscovici, S. (1973). Foreword. In C. Herzlich (Ed.), Health and Illness: A Social Psychological Analysis (pp. ix-xiv). London/New York: Academic Press.

[18] Moscovici, S. (2000) Social Representations. Explorations in Social Psychology. Cambridge: Polity Press.

[19] Moscovici, S. (2011). An essay on social representations and ethnic minorities. Social Science Information, 50(3-4), 442-461.

[20] Park, E. (2009). The Affluent Psyche: European Representations of African Poverty. In T. Teo, P. Stenner, A. Rutherford, E. Park \& C. Baerveldt (Eds.), Varieties of Theoretical Psychology. International Philosophical and Practical Concerns (pp. 245-253). Toronto: Captus University Press.

[21] Park, E. (2011). Social Solidarity in a Transnational Setting: The Cosmopolitan Position. Papers on Social Representations, 20, 6.1-6.19.

[22] Park, E. (2011a). Racism in a Post-Colonial World: European Myths and Truths Effects. In P. Stenner, J. Cromby, J. Motzkau, J. Yen \& Y. Haosheng (Eds.), Theoretical Psychology: Global Transformations and Challenges (pp. 228238). Toronto: Captus University Press.

[23] Park, E. (2012). Cosmopolitan Theories in Psychology. In R. Rieber (Editor-in-Chief), Encyclopedia of the History of Psychological Theories (pp. 224-234). New York City: Springer.

[24] Pogge, T. (2002). World Poverty and Human Rights. Cosmopolitan Responsibilities and Reforms. Cambridge: Polity Press.

[25] Said, E. (1978). Orientalism. New York: Random House.

[26] Spivak, G (2004) 'Righting wrongs'. The South Atlantic Quarterly, 103(2/3): 523-581.Tißberger, M. (2005). Uncertainty and Method: Whiteness, Gender and Psychoanalysis in Germany. European Journal of Women's Studies, 12(3), 315328. 
[27] Wagner, W., Duveen, G., Farr, R., Jovchelovitch, S., Lorenzi-Cioldi, F., Marková, I., \& Rose, D. (1999). Theory and Method of Social Representations. Asian Journal of Social Psychology, 2, 95-125.

\section{Author' biography with Photo}

Valerie de Koeijer received her BA in Social Sciences from University College Roosevelt, Utrecht University and does her MA at the University of Oxford.

Dr. Eri Park works as an Assistant Professor in Psychology at UCR. She received her Ph.D. from the Institute of Social Psychology at The London School of Economics and Political Science. Her interests lie in Global Citizenship Education and Global Justice Research.

Dr. Marcin Sklad, an associate professor of psychology, methods of social sciences and statistics at University College Roosevelt (Utrecht University). His current research focuses on two areas: a) programs enhancing the pedagogical function of education and citizenship education, b) applied cognitive psychology. He completed his Ph.D. in Social Cognitive Psychology at Warsaw University.

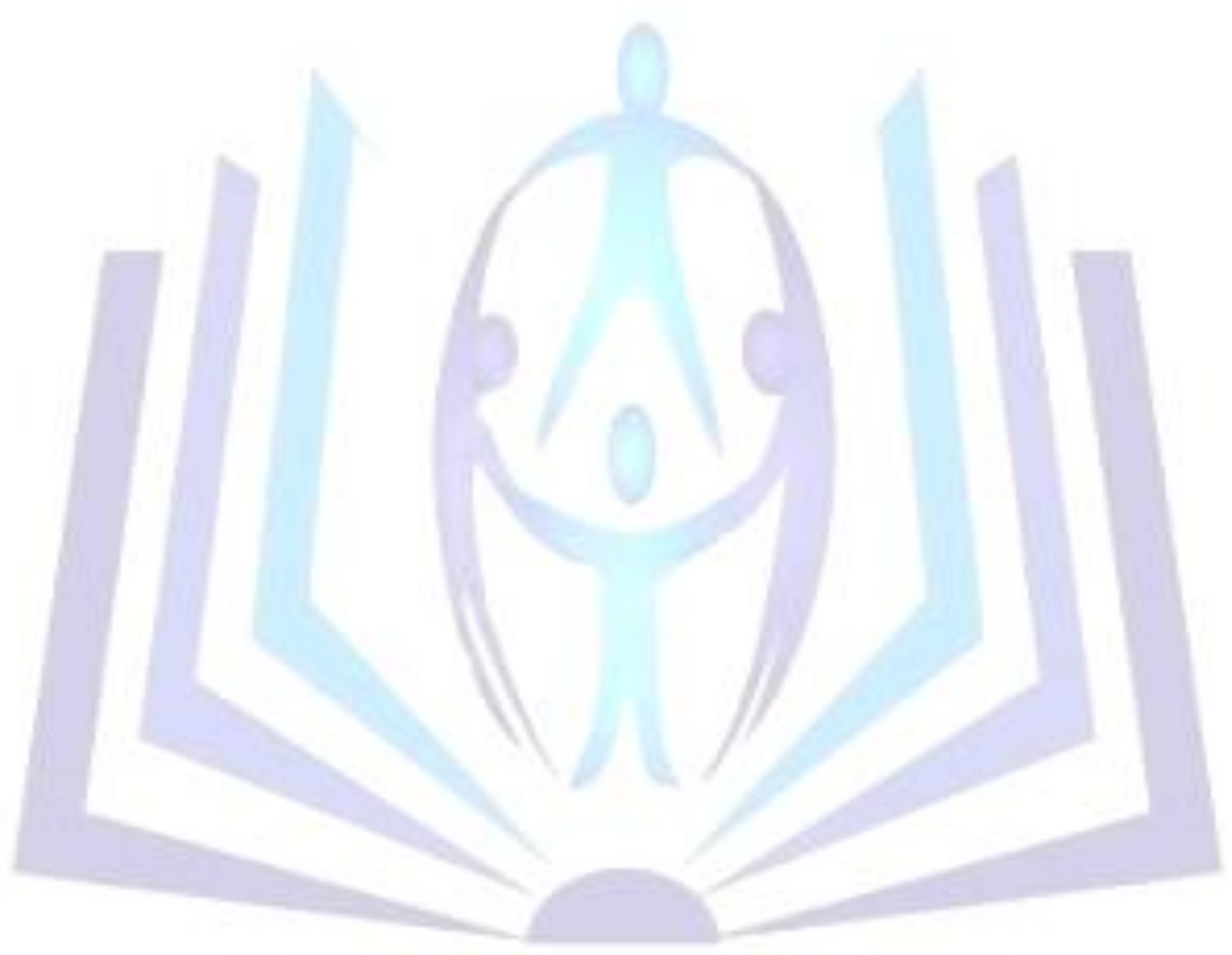

